\title{
EVALUATION OF VEHICLE LIGHTWEIGHTING TO REDUCE GREENHOUSE GAS EMISSIONS WITH FOCUS ON MAGNESIUM SUBSTITUTION
}

\begin{abstract}
Purpose: Vehicle weight reduction represents a viable means of meeting tougher regulatory requirements designed to reduce fuel consumption and control greenhouse gas emissions. This research presents an empirical and comparative analysis of lightweight magnesium $(\mathrm{Mg})$ materials used to replace conventional steel in passenger vehicles with internal combustion engines. The very low density of $\mathrm{Mg}$ makes it a viable material for light weighting given that it 1/3 lighter than aluminium and 3/4 lighter than steel.

Approach: A structural evaluation case study of the 'open access' Wikispeed car was undertaken. This included an assessment of material design characteristics such as bending stiffness, torsional stiffness and crashworthiness to evaluate whether magnesium provides a better alternative to the current usage of aluminium in the automotive industry.

Findings: The Wikispeed car had an issue with the rocker beam width/ thickness (b/t) ratio indicating failure in yield instead of buckling. By changing the specified material, Aluminium Alloy 6061-T651 to Magnesium EN-MB10020 it was revealed that vehicle mass could be reduced by an estimated $110 \mathrm{~kg}$, in turn improving the fuel economy by $10 \%$. This however would require mechanical performance compromise unless the current design is modified.
\end{abstract}

Originality: This is the first time that a comparative analysis of material substitution has been made on the Wikispeed car. The results of such work will assist in the lowering of harmful greenhouse gas emissions (GHG) and simultaneously augment fuel economy.

\section{KEYWORDS}

Lightweight materials, Emission reduction, Greenhouse gas emissions

\section{INTRODUCTION}

Traditionally, internal combustion engines (ICE), fuelled with fossil or alternative fuels that produce different levels of $\mathrm{CO}_{2}$ emissions, have propelled passenger vehicles. However, passenger vehicles currently faces a global challenge in terms of reducing environmental pollution and greenhouse gas emissions (GHG) (Lewis et al., 2014; Palencia et al., 2012). The US, Europe and other countries and regions have introduced stringent regulations to govern the sales and development of passenger vehicles with reduced vehicle mass and 
consequently, carbon dioxide $\left(\mathrm{CO}_{2}\right)$ emissions (Elgowainy et al., 2010; Kim et al., 2010). In response to these challenges, research into vehicle weight reduction (achieved via either component downsizing or materials substitution) has gained popularity for passenger transportation vehicle development (Karden, 2017). For this research, materials substitution will be focused upon. Although conventional steel has a higher density than lightweight materials, it must still be used depending on the vehicle part and application (JimenezEspadafor et al., 2011; Ou et al., 2012). In recent years, vehicle weight has increased due to safety requirements and luxury intent; this has had a concomitant impact upon energy efficiency and $\mathrm{CO}_{2}$ emissions (Patton et al., 2004).

An investigation conducted with 2010-2014 vehicle models in China concluded that $18 \mathrm{~kg}$ mass reduction improved fuel consumption by $0.07 \mathrm{~L} / 100 \mathrm{~km}$ (Hao et al., 2016). Other research illustrated that magnesium: i) is $33 \%$ lighter than aluminium and $75 \%$ lighter than steel or cast-iron components (Wenlong et al., 2016); ii) (in the case of high-purity alloys) has a superior corrosion resistance when compared to conventional aluminium die cast alloys (Zhang et al., 2017); and iii) has better manufacturability when compared to aluminium because solidification is faster due to lower latent heat, thus producing approximately 25$50 \%$ more castings per unit time (Subramanya et al., 2018). Magnesium is the eighth most available element on earth and also composes about $2 \%$ of Earth's crust by weight. The corrosion resistance is also higher than traditional aluminium cast alloys. Magnesium also solidifies faster due to lower latent heat and hence, more castings can be produced than aluminium at a given time. Magnesium was formerly used by Volkswagen Group for their Beetle car, within the air-cooling engine house transmission. General Motors used magnesium in the cross-car beams or instrument panels on the 2012 Cadillac SLS with their quick plastic forming (QPF) technology. The QPF technology consisted of blowing hot forming to make high value automotive components. A lifecycle assessment of a magnesiumbuilt engine block (c.f. Tharumarajah and Koltun, 2007) illustrated its advantageous environmental performance in comparison to functionally equivalent blocks made from aluminium, conventional cast iron and compacted graphite iron. Furthermore, the replacement of an engine cylinder block, front cover and oil pan from conventional materials by die casting magnesium AZ91 caused a reduction of $7 \%$ on total engine weight (Dhingra and Das, 2014). 
Numerous engineers have studied specialized alloys to reduce vehicle weight but traditionally, aluminium and cast iron have been used (Haselhuhn et al., 2017). To date, research that focuses upon an assessment of lightweight materials to reduce vehicle weight remains scant. Consequently, this research paper aims to: i) review current best-practice technologies in manufacturing passenger vehicles using steel, aluminium and magnesium and report upon the effects of light weighting on fuel consumption and emissions; and ii) conduct a structural evaluation of the Wikispeed car in terms of bending stiffness, torsional stiffness, and crashworthiness. Concomitant objectives were to: assess the environmental impact reduction anticipated by utilising magnesium light-weighting; and provide pragmatic design recommendations to reduce the vehicle mass by lightweight material substitution.

\section{WEIGHT REDUCTION USING LIGHTWEIGHT MATERIALS}

The body structure presents the greatest opportunity to reduce vehicle weight with further reductions being made possible by downsizing other components such as the engine (Varney et al., 2017). Vehicle mass reduction can occur in minor accumulative ways or over the entire vehicle re-design (Böhme and Frank, 2017; Li et al., 2017). In order to contextualise the various approaches available, due consideration should first be given to: the classical technology types; and automobile industry plans.

\section{Classical Technology Types}

Classical weight reduction types include changing the materials used to design and build vehicles (Cumming, 1998). Changes in material composition used for modern vehicle manufacture over the period 1950-2010 are illustrated in Figure 1 (Taub et al., 2007). By the 1950s vehicle material manufacturing was made from low-carbon steel, which became greatly diversified to higher strength steels in the 1970's. Thereafter and post 2000, the usage of mixed materials aluminium and steel became dominant.

$<$ Insert Figure 1 about here>

Traditionally, high strength steel was used to develop auto-body parts because they have higher yield strength and failure strength than mild steel (Betancur et al., 2017; Li et al., 2003; Sternlund et al., 2017). Using high strength steel as a sheet in any vehicle body part increases the absorbing energy of the component and also increases its resistance to plastic deformation (Dlugosch et al., 2017; Klassen et al., 1998). High strength steel has low 
fabrication costs and is a cheaper raw material than aluminium and magnesium (Fridlyander et al., 2002; Hourmand et al., 2015). More recently, car manufacturers have increasingly adopted aluminium to augment fuel economy and meet light weighting legislations despite its high cost (Sun et al., 2017). Schbert et al. (2001) devised a total distribution of costs for typical car structures made from steel, aluminium, magnesium and titanium. Ungureanu et al. (2007) developed a sustainability model to quantify the total costs of a vehicle throughout its lifecycle and presented a quantitative comparison of aluminium and steel alloys to assess a vehicle's economic and environmental performance. This comparative analysis demonstrated that by using traditional steel, the vehicle BIW structure is very economical and as the vehicle's usage increases over a 10-year period, the materials and use costs increase as compared to using aluminium (refer to Figure 2).

\section{<Insert Figure 2 about here>}

\section{Rising Weight Reduction Technologies and Automobile Industry Plans}

In recent years, vehicle manufacturers have issued a plethora of product development announcements to provide a clear indication of the various weight reduction technologies being researched (Attaran, 2017; Nikowitz, 2016). Indeed, almost all manufacturers have produced a generic statement of intent on vehicle mass reduction, reduction of greenhouse emissions and a vision for future fuel economy (Isenstadt et al., 2016; Sarlioglu et al., 2017; Suh and Cho, 2017; Webb and Wilson, 2017). For example, in 2014 Ford presented a sedan named 'Ford Fusion' and redesigned the suspension and powertrain parts with total mass reduction $24 \%$. Ford also substituted traditional steel with aluminium on the brake rotors, doors, sills and front sub frame while magnesium was used in the transmission and front door castings (Pinamonti et al., 2017). Ford also reiterated its intension to reduce its vehicles' weight by 250-70 pounds per model from 2015 to 2020 (Gur, Yuksel and Pan, Jian and Li, Wanlu and Wagner, 2016; Xue et al., 2016). Toyota used material slicing technology to produce a lightweight car seats with a weight reduction of anywhere between $7 \mathrm{~kg}$ to $25 \mathrm{~kg}$ by reducing the car seat volume by $72 \%$. Toyota also plan to reduce the overall weight of corolla by 30\% (Jostins and Kendall, 2017; Onar et al., 2016). Similarly, BMW introduced 'efficient lightweight' where every car manufactured uses: aluminium in the front and chassis; magnesium alloys for the engine and drivetrain; and carbon fibre for passenger cells (Henriksson and Johansen, 2016; Nikowitz, 2016). Audi commercialized their concept of weight reduction by substituting aluminium in their vehicle bodies but limited their 
production to lower performing vehicles as compared to their luxury vehicles (Regensburger et al., 2015). Other car manufacturers (such as General Motors, The Volkswagen Group (Audi, Skoda etc.) have not been as outspoken as Ford or Toyota, yet they have indicated achievable weight reduction targets to induce the commercialization of increased fuel economy (He, 2017). The extant literature thus illustrates that automobile manufacturers use various different measures to improve a vehicle's environmental performance albeit, rarely release any detailed technical information to the general public (Hardwick and Outteridge, 2016; Lim, 2016; Rana and Singh, 2016). Nevertheless, the academic discourse that automobile manufacturers are utilising weight reduction technology to develop innovative vehicle designs that reduce greenhouse gas emissions (Fragner et al., 2016).

Automotive engineers refer mass-reduction of vehicle to 'weight creep', in which as the car size increases the mass automatically increases, where innovative material substitutions on the engine or smaller body parts of the car are common (Holmes, 2017; Jinturkar et al., 2017; Muthuraj et al., 2017). Table 1 presents a componential analysis of mass reduction technologies applied to a car system and secondary parts - cross referenced to materials used and the manufacturer.

<Insert Table 1 about here>

\section{LIGHTWEIGHTING EFFECTS AND MAGNESIUM APPLICATION}

To illustrate light weighting effects, Ding et al. (2016) conducted a sensitivity analysis study to show different energy savings on automobile parts in China by replacing them with aluminium. Results recorded over a vehicle life cycle of $200,000 \mathrm{~km}$ driving revealed that when the typical steel parts were replaced with aluminium parts, the vehicle consumed 1,447 to 1,590 litres less gasoline than it would have with steel parts used. A tailored model to assess the environmental benefits by light weighting on diesel turbocharged vehicles was presented by Delogu et al., ( 2016) based upon fuel reduction value (FRV). Their results showed the FRV was within the range of $0.115-0.143$ and $0.142-0.388 \mathrm{~L} / 100 \mathrm{~km} \times 100 \mathrm{~kg}$, respectively, for mass reduction only and powertrain adaptation purposes. Del Pero et al., (2017) performed a life-cycle assessment of 2015 European market vehicle case studies to allow a method to estimate fuel consumption reduction by means of FRV. The authors concluded that the method should be extended to the mass induced energy consumption modelling to electric and hybrid vehicles, to highlight the benefits of light weighting in the 
passenger car vehicles sector. Further development of light weighting materials shows the substitution of glass fibres by natural cellulose and kenaf for automobile components (Boland et al., 2016). Though the use of natural cellulose, the life cycle greenhouse gas emissions were reduced by $18.6 \%$ with powertrain resizing, and $7.2 \%$ without it. By using kenaf composite component, fuel energy consumption was reduced by $6.0 \%$. Ehsani et al. (2016) proposed a new mechanical model for fuel consumption and $\mathrm{CO}_{2}$ for passenger car vehicles, and investigated three types of tolling parameters such as temperature, asphalt efficiency, and fuel efficiency.

At present, magnesium is primarily utilised in the die casting process and is a key material to replace steel (Tang, 2017). Consequently, various studies have been undertaken to review the performance of magnesium components and/ or its impact upon the environmental. For example, Park and Kwon (2015) welded magnesium alloy to investigate the dashboard panel die to be applied for the warm die technology for vehicles. The thermal simulation performed proved that the temperature distribution could be controlled uniformly. Koulton et al., (2016), performed a sensitivity analysis of a convertor housing using magnesium in the die-casting, trimming and finishing processes; their study (ibid) demonstrated that a reduction in total greenhouse gas emissions could be readily achieved. Kiani et al. (2014) conducted a structural optimization on the 1996 Dodge Neon car model, to develop a lightweight car design. The authors replaced 22 steel parts with magnesium AZ31 and the design optimization resulted in saving $46.7 \mathrm{~kg}$ of overall weight and an approximate mass reduction of $44.3 \%$ when compared to the initial steel design. These aforementioned examples, demonstrate the superior performance that magnesium offers as a substitute lightweight material in various (not all) applications.

\section{MECHANICAL ANALYSIS AND DISCUSSION OF THE WIKISPEED CAR}

To provide a case study example of vehicle light weighting that could reduce greenhouse gas emissions using magnesium substitution, an evaluation of the Wikispeed car is presented. The computer aided design (CAD) graphics for the Wikispeed car where downloaded from www.wikispeed.org and are available free of charge as an open source. The finite element analysis results are verified using hand calculations thus presenting a comparative analysis for the case study example. Hand calculations were made for three scenarios, namely i) bending stiffness, ii) body torsion, and iii) crashworthiness. Such calculations are comparatively crude (when compared to finite element analysis (FEA)) as they provide 'ball 
park' values that are subsequently used to determine whether the FEA results are reliable or not. The software 'ANSYS Static Structural' (version 14) was used as a simulation environment and provided finite elements to model the behaviour of any material applied to the presented three scenarios.

\section{Research Approach}

In this case study, FEA was performed to examine the Wikispeed chassis for light weighting opportunities with respect to: i) body bending the rockers (or longitudinal tubes); ii) body torsion - again the rockers but also the chassis as a whole; and iii) crash safety - mainly in the front crash structure. The iterative research approach used in this research paper is shown in Figure 3 and is divided into two phases, namely; i) hand calculations; and FEA. The combination of both analysis results were used to develop the virtual model created using FEM tools and the model was updated based on the correlation process. Figure 4 shows the Wikispeed body structure, and chassis to perform FEA.

<Insert Figure 3 about here>

$<$ Insert Figure 4 about here>

Table 2 considers the implications on chassis mass and cost of directly substituting Aluminium Alloy 6061-T651 with the two alternative materials, without making any potentially necessary structural design modifications.

$<$ Insert Table 2 about here>

\section{Bending stiffness of the car}

FEA was carried out on one of the four identical rocker beams (refer to Figure 5) going through the car; it was found that with aluminium rockers, the maximum bending moment before reaching the plastic limit is $8.27 \mathrm{kNm}$ per rocker. The same calculations made with steel and magnesium revealed an increase in the strength of the beam by $286 \%$ and a cost reduction of $33.5 \%$ albeit, the weight increased by $289 \%$ - formulae used to calculate these values are reproduced in Appendix 1: Bending Formulae.

<Insert Figure 5 about here> 
Magnesium presents an alternative choice because it is the lightest of the three materials and only $64.1 \%$ of the weight of aluminium and $22.2 \%$ of steel. The reduced weight comes at a price because magnesium is $37.4 \%$ weaker than aluminium and $78.1 \%$ weaker than steel although the price is roughly the same as aluminium (refer to Table 3).

<Insert Table 3 about here>

From the results, it can be calculated that with a wheel-base of $2,540 \mathrm{~mm}$ and the beam made from steel it is possible to load the beam with around $18.6 \mathrm{kN}$ without it failing. With the beam been made from aluminium or magnesium, it would be possible to load the beam with around $6.5 \mathrm{kN}$ and $4.1 \mathrm{kN}$ respectively if the load is placed midway between the wheels. The bending moment and shear force diagrams for $100 \%$ structural steel are shown in Figure 6. It can be seen that the maximum shear force is $21,620 \mathrm{~N}$.

\section{$<$ Insert Figure 6 about here>}

As the rockers have been made from a square tube have, the width-to-thickness $(b / t)$ ratio of 33.9 meaning that the beam will fail in yielding and not buckling. The desired structural resonance frequency should be in the region of $22-25 \mathrm{~Hz}$. Calculations made to determine the body stiffness to reach a structural resonance frequency of $25 \mathrm{~Hz}$. The measured mass of the chassis in ANSYS software was $425 \mathrm{~kg}$, and by using the density of the steel and magnesium the weight saving from steel to magnesium is $125 \mathrm{~kg}$ but there is a lower stiffness using magnesium (refer to Table 4). This difference can be removed by changing the simple design of the cross section of the beam and adding a stiffening plate that is often incorporated in most car bodies.

$<$ Insert Table 4 about here>

Therefore, evaluating the results from the bending stiffness of the car chassis, the material should be changed from aluminium to magnesium because the hand calculation matches the FEA presented in this research. Magnesium will also save $3 \mathrm{~kg}$ weight per beam which is 12 $\mathrm{kg}$ on the whole chassis for the same material price per beam. This recommendation must be assessed via torsion and body crash analysis to measure its effect upon the overall engineering performance of to the Wikispeed car. The limitation of this simulated analysis 
presented, is that it only takes one of the rockers into consideration. This can be positive, as it is possible to load the car with twice the load however, the calculation presented provides a rough guide only as it was based upon a single point load in the centre between the wheels. In real life, there would be more than one loading point and these would not be exactly positioned midway between the wheels. Furthermore, this estimate does not include the load for the engine, luggage, steering controls along with other equipment mounted in the car. One of the issues with the Wikispeed car is their choice of profile for the rockers; with the b/t ratio of 34 , the rockers are going to fail by yielding and not by buckling.

\section{Torsional stiffness of the car}

Akin to bending, a rocker manufactured from steel has the least amount of angular twist when $500 \mathrm{Nm}$ torque is applied to the one end (refer to Table 5). More specifically the rocker twist at $5.92^{\circ}$ is less when made from steel instead of aluminium, which is a reduction of $66.4 \%$. Whereas a rocker made from magnesium instead of aluminium incurs a $62.5 \%$ increase in twist, which is a further $5.57^{\circ}$ twist in the magnesium beam. When the torque of $500 \mathrm{Nm}$ is applied, the shear stress in the beam is $70.43 \mathrm{MPa}$. All the formulae used for calculations from this section can be found in Appendix 2: Torsion formulae.

\section{<Insert Table 5 about here>}

An examination of energy in the rocker and hinge pillar while twisted reveals that the energy going into the rocker was greater than the energy going into the hinge pillar. This means that the rocker is the area to optimize in order to maximize the torsional stiffness. The initial calculations reveal that from a design for torsion stance, steel would be the most suitable material. However, although this may be true, and steel is by far the cheapest of the three materials investigated, it also has the highest density and this weight implication would negatively impact fuel economy. As high fuel economy is a key design criterion for the vehicle, the degree to which torsional performance compromise can be made in favour of reducing weight, should be the main consideration. Hence, a compromise between magnesium and aluminium should be considered and consideration given to whether a weight saving of $43 \%$ justifies having a beam with half the torsional performance, $8.91^{\circ}$ for aluminium vs $14.48^{\circ}$ for magnesium - Figure 7 illustrates that the most deformation occurs at the top frame. 
Caution should be taken when examining results because aluminium seems stronger than steel and in most cases, that would not be the reality. The reason for this enigmatic finding is that the calculations are based on a worst-case scenario where the used material properties used the weakest aluminium which is stronger than the weakest steel. Had the calculations been on a best-case principle, this finding would have been reversed. Reverting back to the $\mathrm{b} / \mathrm{t}$ ratio, by choosing a ratio above 60 could potentially increase the stiffness of the rockers while reducing the weight. Interestingly, an examination of joint efficiency reveals that the lowest efficiency is found using steel with $43 \%$ while using aluminium or magnesium is much higher at $68.93 \%$ and $77.42 \%$ respectively which means the joint is more rigid and more of the beam stiffness is utilized. The torsional stiffness has also been evaluated based on the geometry of the car. This showed a fairly rigid car with a respectable $12,879.8 \mathrm{Nm} / \mathrm{deg}$ which is attributable to the incorporation of a roof that increases the stiffness of the body.

\section{Crashworthiness}

The four identical rockers used in the Wikispeed car have been evaluated for the load they can withstand before they yield in a crash. From these results, an average has been built for the evaluation. Manufacturing rockers from steel gives the highest yield strength at a massive $329.73 \mathrm{kN}$ per beam. While the aluminium rocker yields at $93.9 \mathrm{kN}$ lower than steel - a reduction of $28.4 \%$ and a magnesium rocker would be the first to yield at $90.57 \mathrm{kN}$ - a reduction of $61.6 \%$ compared to aluminium and $73.8 \%$ compared to steel. These results have been found using the critical buckling stress (refer to Table 6). All the formulae used for the calculations from this section can be found in Appendix 3: Crashworthiness.

\section{$<$ Insert Table 6 about here>}

These aforementioned findings mean that during a head-on collision, the four rockers are able to withstand $137 \mathrm{G}$ before they are going to yield if they are made from aluminium, $191 \mathrm{G}$ if made steel and $52 \mathrm{G}$ if made from magnesium. Another method to evaluate the crush strength of the rockers is to use the yield strength of the material used as seen in Table 7 . With this method the aluminium rocker is the strongest and is able to withstand $129.64 \mathrm{kN}$, which is $11.42 \mathrm{kN}>$ steel and $68.21 \mathrm{kN}>$ magnesium, or $9.6 \%>$ steel and $111.0 \%>$ magnesium. 
When evaluating the crush efficiency, the eligible crush distance was taken from the front bumper to the fire-wall or where the rockers begin. Other parameters (refer to Table 8) revealed a crush efficiency of $126.72 \%$, which means that for the car to be able to stop within the eligible crush distance it cannot exceed a maximum deceleration of $28 \mathrm{~m} / \mathrm{s}^{2}$. A $26.72 \%$ longer crush zone would be needed for it to be able to do so, although this is not the only issue. The way that the crash beams have been orientated means that they are not going to buckle or yield but rather collapse. However, the cross bar needs to be orientated in this way to distribute the load between both sides. The reasons for this configuration in design (which is unlike most car manufacturing designs) could be because the thickness of the beams might give it the needed rigidity to act as a good crash structure. The results suggest that the Wikispeed car is stronger than needed, so with magnesium being the same price as aluminium but with a $36 \%$ weight reduction, it seems to be the obvious choice. Nevertheless, the price calculated is from the price per $\mathrm{kg}$ and does not account for any possible extra manufacturing costs. Furthermore, the torsional stiffness is $62.5 \%$ lower than aluminium, this could suggest you need internal stiffeners or ribs in the beams, which would make them more expensive to manufacture and thereby reduce the weight saving.

\section{FUTURE RECOMMENDATIONS}

In terms of strength, the Wikispeed rocker needs to withstand larger dynamic forces other than just the static loading. Bending stiffness requirements are established to allow a bending resonance within the desired $22-25 \mathrm{~Hz}$ range, at which the car will feel most comfortable and should not shake while driving and loaded. For torsional stiffness, the calculated values for steel and aluminium were way below the widely established value of $12,879.8 \mathrm{Nm} / \mathrm{deg}$, which means that the customer would experience poor handling capabilities, from relative deformations. The crash safety results suggest that front crash structure is too weak, and that the car would only be deemed safe if the structure achieved a safety factor of 0.93 in its current set up - where all the beams are horizontal to the front of the car. Therefore, further investigation into the car's design should be undertaken. For example, if designed with a high $\mathrm{b} / \mathrm{t}$ ratio, then the stiffness would be increased and possible weight and cost might be lower due to lower required thickness. Other recommendations worthy of further research are to: 
- add braces or a lattice structure to the vehicle's chassis to account for reduction of torsional performance due to material change;

- conduct further analytical calculations, as well as numerical simulations, to gain further insight into the vehicle's mechanical performance;

- establish how the bodywork affects both body stiffness and crashworthiness and use the findings to optimise; and

- refinement and development for the design of the magnesium chassis and addition of crash structures to the fibre reinforced composite bodywork.

\section{CONCLUSIONS}

Automotive materials play an important part in vehicle performance and fuel consumption. This assessment concludes that car body light weighting can significantly improve fuel efficiency and thus, reduce $\mathrm{CO}_{2}$ emissions. Due to the tougher EU legislations being introduced on reducing $\mathrm{CO}_{2}$ emissions, automotive manufacturers are increasingly applying light weight as a technological solution to obtain desirable improvements. Vehicle mass reduction can be obtained through downsizing, but also through substitution of the traditional automotive materials by lightweight materials such as magnesium. Although aluminium alloy application has gained prominence, magnesium proves to be a promising contender to meet future demands of passenger vehicles. With the key design criteria of the Wikispeed being high fuel economy, the potential benefits highlighted in this paper from substituting aluminium alloy 6061-T651 for magnesium EN-MB10020 are noteworthy. The ability to improve the fuel economy by $10 \%$ and reduce the production cost at the same time is useful information for any designer to be presented with, especially those in the open-source crowdfunded domain. However, as discussed above, this material change will have mechanical performance implications which will need to be addressed, in particular adapting the design to improve torsional performance. It is therefore advisable for designers to consider changing the material of the chassis to magnesium EN-MB10020 while implementing braces; although this will add more material to the vehicle it will be compensated for in the large reduction in vehicle mass of $110 \mathrm{~kg}$. 


\section{REFERENCES}

Attaran, M. (2017) The Rise of 3-D Printing: The Advantages of Additive Manufacturing Over Traditional Manufacturing. Business Horizons Vol. 60, No. 5, pp. 677-688. DOI: Https://Doi.Org/Https://Doi.Org/10.1016/J.Bushor.2017.05.011

Bach, E.W., Rompage, A.J. and Matsuura, H. (2017) Front Pillar for a Vehicle Body. Honda Motor Company Ltd, 2017. U.S. Patent: 9,598,112.

Baskara Sethupathi P., Muthuvel A., Prakash N. and S.W.L. (2015) Numerical Analysis of a Rotor Disc for Optimization of the Disc Materials. Journal of Mechanical Engineering and Automation, Vol. 5, No. 3B, pp. 5-14. DOI: Https://Doi.Org/10.5923/C.Jmea.201502.02

Betancur, E., Mejía-Gutiérrez, R., Osorio-Gómez, G. and Arbelaez, A. (2017) Design of Structural Parts for a Racing Solar Car, Advances on Mechanics, Design Engineering and Manufacturing. $\quad$ Springer, pp. 25-32. DOI: Https://Doi.Org/Https://Doi.Org/10.1007/978-3-319-45781-9_3

Bhattacharya, S. and Alpas, A.T. (2017) Tribology of Aluminum and Aluminum Matrix Composite Materials for Automotive Components, In: Lightweight and Sustainable Materials for Automotive Applications. London: CRC Press.

Böhme, T.J. and Frank, B. (2017) Hybrid Systems, Optimal Control and Hybrid Vehicles: Theory, Methods And Applications. London: Springer.

Boland, C.S., De Kleine, R., Keoleian, G.A., Lee, E.C., Kim, H.C. and Wallington, T.J. (2016) Life Cycle Impacts of Natural Fiber Composites for Automotive Applications: Effects of Renewable Energy Content and Lightweighting. Journal of Industrial Ecology, Vol. 20, No. 1, pp. 179-189. DOI: Https://Doi.Org/10.1111/Jiec.12286

Britto, V.A.J., Karmakar, S., Muthuveeraswamy, M. and Natarajasundaram, B. (2016) High Speed Booming Noise Reduction in Passenger Car by Application of Cost Optimized Nvh Solution, In: Sae Technical Paper. Sae International. DOI: Https://Doi.Org/10.4271/2016-28-0039

Cumming, B.S. (1998) Innovation Overview and Future Challenges. European Journal of Innovation Management, Vol. 1, No.1, pp. 21-29. DOI: https://doi.org/10.1108/14601069810368485

Delogu, M., Del Pero, F. and Pierini, M. (2016) Lightweight Design Solutions in the Automotive Field: Environmental Modelling Based on Fuel Reduction Value Applied to Diesel Turbocharged Vehicles, Sustainability, Vol. 8, No. 11, p. 1167. DOI: $10.3390 / \mathrm{su} 8111167$ 
Dhingra, R. and Das, S. (2014) Life Cycle Energy and Environmental Evaluation of Downsized vs. Lightweight Material Automotive Engines. Journal of Cleaner Production, Vol. 85, pp. 347-358. DOI: Https://Doi.Org/Https://Doi.Org/10.1016/J.Jclepro.2014.08.107/

Ding, N., Gao, F., Wang, Z. and Yang, J. (2016) Life Cycle Energy and Greenhouse Gas Emissions of Automobiles Using Aluminum in China. Journal of Industrial Ecology, Vol. 20, No. 4, pp. 818-827. DOI: Https://Doi.Org/10.1111/Jiec.12298

Dlugosch, M., Volk, M., Lukaszewicz, D., Fritsch, J. and Hiermaier, S. (2017) Suitability Assessments for Advanced Composite-Metal Hybrid Material Systems in Automotive Crash Structural Applications. International Jouranl of Automotive Composites, Vol. 3, No. 1, pp. 14-28. DOI: https://doi.org/10.1504/IJAUTOC.2017.086513

Du, C.P. and, Xu, D.F. (2013) Application of Energy-Saving Magnesium Alloy in Automotive Industry, In: Resources and Sustainable Development, Advanced Materials Research. Trans Tech Publications, Vol. 724-737, pp. 2244-2247. DOI: Https://Doi.Org/10.4028/Www.Scientific.Net/Amr.734-737.2244

Ehrlich, P., Erlacher, M., Hofer, B., Hoermann, R., Maier, S., Planka, F., Rucker, M., Rud, S., Spary, A. and Zachnegger, H. (2017) Load-Bearing Structure of a Motor Vehicle and Method for Producing the Same. MAGNA STEYR Engineering AG \& Co KG. U.S. Patent: 9,567,013.

Ehsani, M., Ahmadi, A. and Fadai, D. (2016) Modeling of Vehicle Fuel Consumption and Carbon Dioxide Emission in Road Transport. Renewable and Sustainable Energies Review, Vol. 53, pp. 1638-1648, DOI: Https://Doi.Org/Https://Doi.Org/10.1016/J.Rser.2015.08.062

Elgowainy, A., Han, J., Poch, L., Wang, M.Q., Vyas, A.D., Mahalik, M. and Rousseau, A. (2010) Well-To-Wheels Analysis of Energy Use and Greenhouse Gas Emissions of Plug-In Hybrid Electric Vehicles 154. (No. ANL/ESD/10-1). Argonne National Laboratory (ANL).

Fragner, W., Baumgartner, K., Suppan, H., Hummel, M., Bösch, D., Höppel, H.-W. and Uggowitzer, P.J. (2016) Using Scrap in Recycling Alloys for Structural Applications in the Automotive Industry, In: Grandfield, J. (Ed.), Light Metals 2014. London: Springer International Publishing, pp. 349-353. DOI: Https://Doi.Org/10.1007/978-3319-48144-9_59

Fridlyander, I.N., Sister, V.G., Grushko, O.E., Berstenev, V. V, Sheveleva, L.M. and Ivanova, L.A. (2002) Aluminum Alloys: Promising Materials in the Automotive 
Industry. Metal Science and Heat Treatment. Vol. 44, No. 9-10, pp. 365-370. DOI: Https://Doi.Org/10.1023/A:1021901715578

Gur, Y., Pan, J., Li, W. and Wagner, D.A. (2016) Development of Vehicle Dash and Floor Subsystem Sound Packages for Lightweight Vehicle. Inter-Noise Noise-Con Congress and Conference Proceedings. NoiseCon16, Providence, Rhode Island, USA. pages 1-871.

Hao, H., Wang, S., Liu, Z. and Zhao, F. (2016) The Impact of Stepped Fuel Economy Targets on Automaker's Light-Weighting Strategy: The China Case. Energy. Vol. 94, 755765. DOI: Https://Doi.Org/Https://Doi.Org/10.1016/J.Energy.2015.11.051

Hardwick, A.P. and Outteridge, T. (2016) Vehicle Lightweighting Through the Use of Molybdenum-Bearing Advanced High-Strength Steels (Ahss). International Journal Life Cycle Assessment. Vol. 21, No.11, pp. 1616-1623. DOI: https://link.springer.com/article/10.1007/s11367-015-0967-7

Haselhuhn, A.S., Sanders, P.G. and Pearce, J.M. (2017) Hypoeutectic Aluminum-Silicon Alloy Development for Gmaw-Based 3-D Printing Using Wedge Castings. International Journal of Metal Casting. Vol. 11, No. 4, pp. 843-856. DOI: https://link.springer.com/article/10.1007/s40962-017-0133-z

He, P.H.Y. (2017) Hot Stamping Advanced Manufacturing Technology of Lightweight Car Body. Singapore: Springer.

Heinig, K.-P., Stephenson, D.A. and Beyer, T.G. (2017) Thermal Response of Aluminum Engine Block During Thermal Spraying of Bores: Comparison of FEA and Thermocouple Results. SAE International Journal of Material and Manfacturing. Vol. 10, No. 3, pp. 360-365. DOI: Https://Doi.Org/10.4271/2017-01-0451

Henriksson, F. and Johansen, K. (2016) An Outlook on Multi Material Body Solutions in the Automotive Industry - Possibilities and Manufacturing Challenges, In: SAE Technical Paper 2016-01-1332. SAE International. DOI: Https://Doi.Org/10.4271/2016-01-1332 Holmes, K.J. (2017) A Century of Environmental Technologies for Light-Duty Vehicles. SAE International Journal of Engines. Vol. 10, No. 2, pp. 160-172. DOI: https://doi.org/10.4271/2017-01-0119

Hourmand, M., Farahany, S., Sarhan, A.A.D. and Noordin, M.Y. (2015) Investigating the Electrical Discharge Machining (EDM) Parameter Effects on Al-Mg2Si Metal Matrix Composite (MMC) For High Material Removal Rate (MRR) and Less EWR-RSM Approach. International Journal of Advanced Manufacturing Technolology. Vol. 77, No. 5-8, pp. 831-838. DOI: https://link.springer.com/article/10.1007/s00170-014- 
$6491-2$

Isenstadt, A., German, J., Bubna, P., Wiseman, M., Venkatakrishnan, U., Abbasov, L., Guillen, P., Moroz, N., Richman, D. and Kolwich, G. (2016) Lightweighting Technology Development and Trends in US Passenger Vehicles. International Council on Clean Transportation, Available via: https://www.theicct.org/sites/default/files/publications/ICCT_PVtech_lightweighting_ wp2016-25.pdf [Accessed: March, 2018].

Jimenez-Espadafor, F.J., Marín, J.J.R., Villanueva, J.A.B., García, M.T., Trujillo, E.C. and Ojeda, F.J.F. (2011) Infantry Mobility Hybrid Electric Vehicle Performance Analysis and Design. Applied Energy Vol. 88, No. 8, pp. 2641-2652. DOI: Https://Doi.Org/Https://Doi.Org/10.1016/J.Apenergy.2011.02.010

Jinturkar, A., Channa, R., Mistry, R. and Deshmukh, B. (2017) Weight Reduction of FSAE Vehicle Using Triz Principle, In: International Conference on Research Into Design. Vol. 1, pp. 861-870. DOI: https://link.springer.com/chapter/10.1007/978-981-103518-0_74

Jostins, J. and Kendall, K. (2017) Interfaces, Cracks and Toughness: City Cars Made from Composites, In: Beaumont, P.W.R., Soutis, C., Hodzic, A. (Eds.), The Structural Integrity Of Carbon Fiber Composites: Fifty Years of Progress and Achievement of The Science, Development, andnd Applications. London: Springer International Publishing. pp. 645-663. DOI: Https://Doi.Org/10.1007/978-3-319-46120-5_22

Karden, E. (2017) Development Trends for Future Automobiles and their Demand on the Battery, In: Lead-Acid Batteries For Future Automobiles. Elsevier, pp. 3-25. DOI: https://doi.org/10.1016/B978-0-444-63700-0.00001-5

Karpagaraj, A., Siva Shanmugam, N. and Sankaranarayanasamy, K. (2016) Studies on Mechanical Behavior and Microstructural Analysis of Tailor Welded Blanks of Ti6al-4v Titanium Alloy Sheet. Journal of Materials Research. Vol. 31, No. 4, pp. 2186-2196. DOI: Https://Doi.Org/Doi:10.1557/Jmr.2016.152

Kiani, M., Gandikota, I., Rais-Rohani, M. and Motoyama, K. (2014) Design of Lightweight Magnesium Car Body Structure Under Crash and Vibration Constraints. Journal of Magnesium and Alloys. Vol. 2, No. 2, pp. 99-108. DOI: Https://Doi.Org/Https://Doi.Org/10.1016/J.Jma.2014.05.005

Kim, H.-J., Mcmillan, C., Keoleian, G.A. and Skerlos, S.J. (2010) Greenhouse Gas Emissions Payback for Lightweighted Vehicles Using Aluminum and High-Strength Steel. Journal of Industrial Ecology. Vol. 14, No. 6, pp. 929-946. DOI: 
Https://Doi.Org/10.1111/J.1530-9290.2010.00283.X

Klassen, M., Skupin, J., Schubert, E. and Sepold, G. (1998) Development of Seam Imperfections Due to Process Immanent Resonances by Laser Beam Welding of Aluminium Alloys, In: Proceedings Of The Conference On Eklat'98, Hanover, Germany, September 22-23. pp. 297-302.

Koltun, P., Tharumarajah, A. and Ramakrishnan, S. (2016) Life Cycle Environmental Impact of Magnesium Automotive Components, In: Mathaudhu, S.N., Luo, A.A., Neelameggham, N.R., Nyberg, E.A., Sillekens, W.H. (Eds.), Essential Readings In Magnesium Technology. London: Springer International Publishing. pp. 175-180. DOI: Https://Doi.Org/10.1007/978-3-319-48099-2_29

Lewis, A.M., Kelly, J.C. and Keoleian, G.A. (2014) Vehicle Lightweighting vs. Electrification: Life Cycle Energy and GHG Emissions Results For Diverse Powertrain Vehicles. Applied Energy. Vol. 126, pp. 13-20. DOI: Https://Doi.Org/Https://Doi.Org/10.1016/J.Apenergy.2014.03.023

Li, L., Wang, X. and Song, J. (2017) Fuel Consumption Optimization for Smart Hybrid Electric Vehicle During a Car-Following Processing. Mechanical Systems and Signal Processing. Vol. 87, Part B, pp. 17-29. DOI: https://doi.org/10.1016/j.ymssp.2016.03.002

Li, Y., Lin, Z., Jiang, A. and, Chen, G. (2003) Use of High Strength Steel Sheet for Lightweight and Crashworthy Car Body. Materials and Design. Vol. 24, No. 3, pp. 177-182. DOI: Https://Doi.Org/Https://Doi.Org/10.1016/S0261-3069(03)00021-9

Lim, S.-W. (2016) Topology Optimization of Bonnet-Like Plate Using Carbon Fiber Reinforced Thermoplastics Subjected to Different Criteria. MSc Thesis, KTH Royal Institute of Technology, Stockholm, Sweden.

Luo, A.A. (2013) Magnesium Casting Technology for Structural Applications. Journal of Magnesium and Alloys. Vol. 1, No. 1, pp. 2-22. DOI: https://doi.org/10.1016/j.jma.2013.02.002

Mayyas, A.T., Mayyas, A.R. and Omar, M. (2016) Sustainable Lightweight Vehicle Design:

A Case Study in Eco-Material Selection for Body-In-White, In: Lightweight Composite Structures In Transport: Design, Manufacturing, Analysis And Performance. New York: Elsevier Inc. pp. 267-302. DOI: Https://Doi.Org/10.1016/B978-1-78242-325-6.00011-6

Mohamed, M.S. and Ismail, A. (2016) Review on Sheet Metal Forming Process of Aluminium Alloys, In: 17th International Conference on Applied Mechanics and 
Mechanical Engineering - Cairo, Egypt, 19th April. pp. 129-141.

Mucha, J. (2017) Clinching Technology in the Automotive Industry. The Archives in Automotive Enginering. Vol. 76, No. 2, pp. 75-94. DOI: http://dx.doi.org/10.14669/AM.VOL.76.ART4

Muthuraj, R., Thiyagarajan, S., Vignesh, E., Kannan, C. and Praphu, D. (2017) The Disc Gutter Wheel for Commercial Vehicles, A Solution for Overheating Problems With Robustness In Design. SAE Technical Paper 2017-26-0369. DOI: https://doi.org/10.4271/2017-26-0369.

Nikowitz, M. (2016) Advanced Hybrid and Electric Vehicles: System Optimization and Vehicle Integration. London: Springer.

Onar, O.C., Campbell, S.L., Seiber, L.E., White, C.P., Chinthavali, M.S., Tang, L., Chambon, P.H., Ozpineci, B. and Smith, D.E. (2016) Oak Ridge National Laboratory Wireless Charging of Electric Vehicles-Crada Report. Available via: https://info.ornl.gov/sites/publications/files/Pub68349.pdf [Accessed: March, 2018]/

Ou, X., Yan, X., Zhang, X. and Liu, Z. (2012) Life-Cycle Analysis on Energy Consumption and GHG Emission Intensities of Alternative Vehicle Fuels in China. Applied Energy. Vol. $90, \quad$ No.1, pp. 218-224. Https://Doi.Org/Https://Doi.Org/10.1016/J.Apenergy.2011.03.032

Palencia, J.C.G., Furubayashi, T. and Nakata, T. (2012) Energy Use and Co2 Emissions Reduction Potential in Passenger Car Fleet Using Zero Emission Vehicles and Lightweight Materials. Energy. Vol. 48, No. 1, pp. 548-565. DOI: Https://Doi.Org/Https://Doi.Org/10.1016/J.Energy.2012.09.041

Park, D.-H. and Kwon, H.-H. (2015) Development of Warm Forming Parts for Automotive Body Dash Panel Using AZ31b Magnesium Alloy Sheets. International Journal of Precision Enginerring Manufacturing. Vol. 16, No. 10, pp. 2159-2165. DOI: Https://Doi.Org/10.1007/S12541-015-0278-8

Patton, R., Li, F. and Edwards, M. (2004) Causes of Weight Reduction Effects of Material Substitution on Constant Stiffness Components. Thin-Walled Structures. Vol. 42, No. 4, pp. 613-637. DOI: Https://Doi.Org/Https://Doi.Org/10.1016/J.Tws.2003.08.001

Pero, F. Del, Delogu, M. and Pierini, M. (2017) The Effect of Lightweighting in Automotive LCA Perspective: Estimation of Mass-Induced Fuel Consumption Reduction for Gasoline Turbocharged Vehicles. Journal of Cleaner Production. Vol. 154, pp. 566577. DOI: Https://Doi.Org/Https://Doi.Org/10.1016/J.Jclepro.2017.04.013

Pinamonti, S.A., Brancale, D., Meister, G. and Mendoza, P. (2017) A Correlation 
Methodology Between AVL Mean Value Engine Model and Measurements with Concept Analysis of Mean Value Representation for Engine Transient Tests, In: SAE Technical Paper. SAE International. DOI: 10.4271/2017-24-0053

Pradeep, S.A., Iyer, R.K., Kazan, H. and Pilla, S. (2017) Automotive Applications of Plastics:

Past, Present, and Future, In: Kutz, M. (Ed.), Applied Plastics Engineering Handbook (Second Edition), Plastics Design Library. London: William Andrew Publishing, pp. 651-673. DOI: Https://Doi.Org/Https://Doi.Org/10.1016/B978-0-323-39040-8.000316

Rana, R. and Singh, S.B. (2016) Automotive Steels: Design, Metallurgy, Processing and Applications. London: Woodhead Publishing.

Regensburger, J., Biesdorf, F. and Albiez, C. (2015) Aluminium Roof Optimisation in the New Audi Q7. Atz Worldwide. Vol. 117, No. 11/2005, pp. 4-9.

Sarlioglu, B., Morris, C.T., Han, D. and Li, S. (2017) Driving Toward Accessibility: A Review of Technological Improvements for Electric Machines, Power Electronics, and Batteries for Electric and Hybrid Vehicles. IEEE Industrial Applied Magazine. Vol. 23, No. 1, pp. 14-25. DOI: 10.1109/MIAS.2016.2600739

Schubert, E., Klassen, M., Zerner, I., Walz, C. and Sepold, G. (2001) Light-Weight Structures Produced by Laser Beam Joining for Future Applications in Automobile and Aerospace Industry. Jouranl of Materials Processing Technology. Vol. 115, No. 1, pp. 2-8. DOI: Https://Doi.Org/Https://Doi.Org/10.1016/S0924-0136(01)00756-7

Sternlund, S., Strandroth, J., Rizzi, M., Lie, A. and Tingvall, C. (2017) The Effectiveness of Lane Departure Warning Systems-A Reduction in Real-World Passenger Car Injury Crashes. Traffic Injury Prevention. Vol. 18, No. 2, pp. 225-229. DOI: 10.1080/15389588.2016.1230672.

Subramanya, P., Amar, M., Arun, S., Mervin, H. and Shrikantha, R. (2018) Friction Stir Welding of Aluminium Matrix Composites - A Review, In MATEC Web of Conferences. Vol. 144, p. 3002. EDP Sciences. DOI: https://doi.org/10.1051/matecconf/201814403002

Suh, N.P. and Cho, D.H. (2017) Making The Move: From Internal Combustion Engines to Wireless Electric Vehicles, In: The On-Line Electric Vehicle. London: Springer, pp. $3-15$.

Sun, X., Liu, J., Lu, B., Zhang, P. and Zhao, M. (2017) Life Cycle Assessment-Based Selection of a Sustainable Lightweight Automotive Engine Hood Design. Internaitonal Journal of Life Cycle Assessment. Vol. 22, No. 9, pp. 1373-1383. DOI: 
https://link.springer.com/article/10.1007/s11367-016-1254-y

Tang, H.H. (2017) Comprehensive Considerations on Material Selection for Lightweighting Vehicle Bodies Based on Material Costs and Assembly Joining Technologies. International Journal Manufacturing, Materials and Mechanical Engineering. Vol. 7, No. 4, pp. 1-14. DOI: 10.4018/IJMMME.2017100101

Taub A., Krajewski P., Luo A. and Owens, .J.N. (2007) The Evolution of Technology for Materials Processing Over the Last 50 Years: The Automotive Example. Journal Minerals Metalurgy and Materials. Vol. 59, No.2, pp. 48-57. DOI: https://link.springer.com/article/10.1007\%2Fs11837-007-0022-7

Tharumarajah, A. and Koltun, P. (2007) Is There an Environmental Advantage of Using Magnesium Components for Light-Weighting Cars? Journal of Cleaner Production. Vol. 15, No. 11-12, pp. 1007-1013. DOI: Https://Doi.Org/Https://Doi.Org/10.1016/J.Jclepro.2006.05.022

Ungureanu, C., Das, S. and Jawahir, I. (2007) Life-Cycle Cost Analysis: Aluminum Versus Steel in Passenger Cars. The Minerals, Metals and Materials Society. pp. 11-24. Avialable via: http://www.phinix.net/services/Carbon_Management/Lifecycle_Cost_Analysis.pdf [Accessed: March, 2018].

Varney, M., Passmore, M. and Gaylard, A. (2017) The Effect of Passive Base Ventilation on the Aerodynamic Drag of a Generic SUV Vehicle. SAE International Journal of Passenger Cars-Mechanical Systems. Vol. 10, pp. 345-357. DOI: 10.4271/2017-011548

Webb, J. and Wilson, C. (2017) Powering the Driverless Electric Car of the Future, In: Innovation and Disruption at the Grid's Edge. London: Elsevier. pp. 101-122.

Wenlong, S., Xiaokai, C. and Lu, W. (2016) Analysis of Energy Saving and Emission Reduction of Vehicles Using Light Weight Materials. Energy Procedia. Vol. 88, pp. 889-893. DOI: Https://Doi.Org/Https://Doi.Org/10.1016/J.Egypro.2016.06.106

Wikispeed.Org (2017) Car - Wikispeed. Avialable via: Http://Wikispeed.Org/Car [Accessed: March, 2018].

Xue, Z., Elango, A. and Fang, J. (2016) Multidisciplinary Design Optimization of Vehicle Weight Reduction. SAE International Journal of Materials and Manufacturing. Vol. 9, No. 2, pp. 393-399. DOI: http://www.jstor.org/stable/26267453

Zhang, X., Chen, W., Luo, H., Li, S., Zhou, T. and Shi, L. (2017) Corrosion Resistance and Interfacial Morphologies of Novel Fe-Cr-Mo-B Cast Steels in Molten Aluminum. $\begin{array}{lllll}\text { Corrosion } & \text { Science. } & \text { Vol. }\end{array}$ 
https://doi.org/10.1016/j.corsci.2017.05.024 
Figure 1 - The automotive body revolution in materials (Taub et al., 2007).

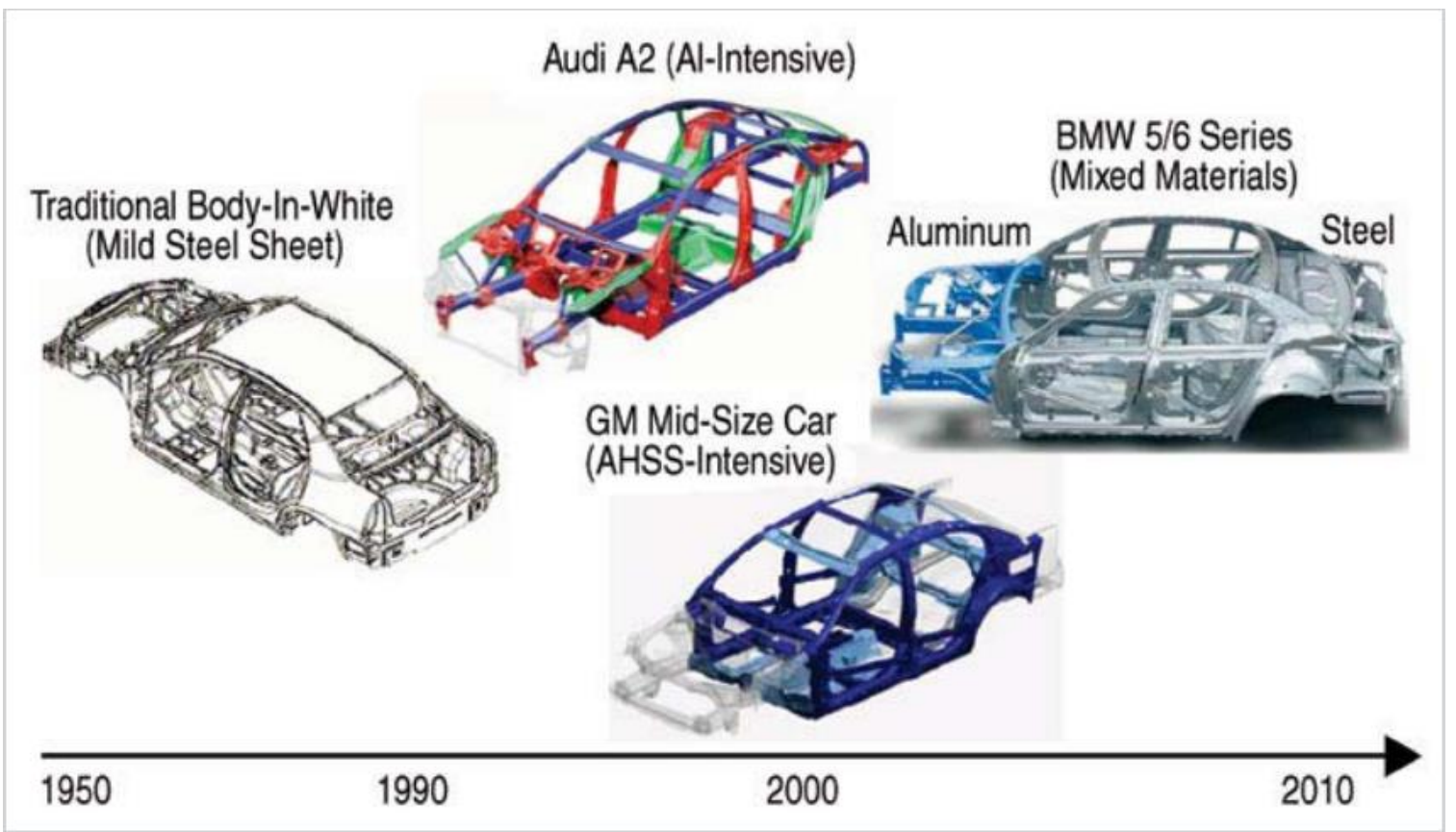


Figure 2 - Aluminium vs. Steel Total Cost Break Down Over a Ten Year Life Cycle (Ungureanu et al., 2007).

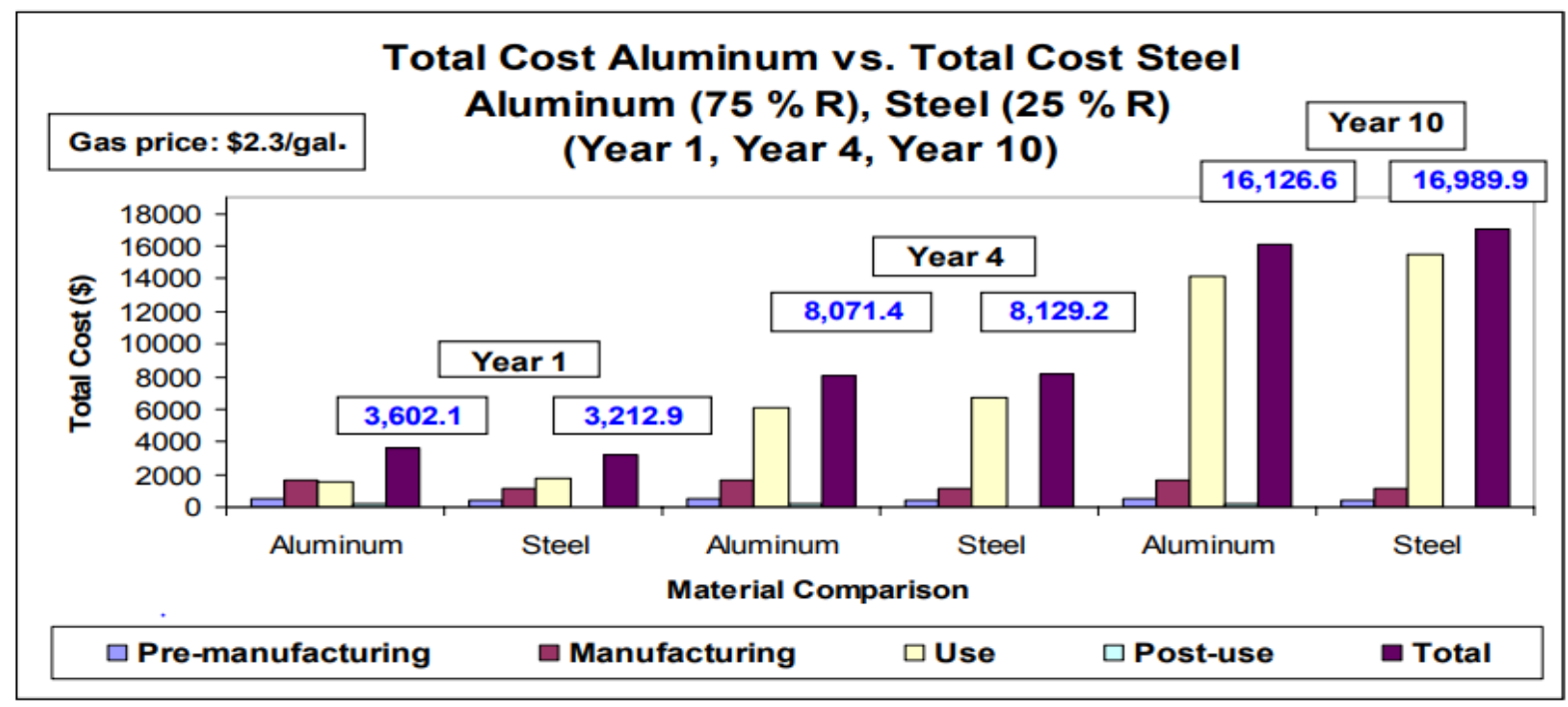


Table 1 - Potential Mass Reduction Technologies for Car Systems and Secondary Parts

\begin{tabular}{lllll}
\hline Car System & Secondary parts & New Material & Automobile maker & Source(s) \\
\hline Body & Doors (4) & Aluminium intensive & Audi, Honda. & $\begin{array}{l}\text { (Bach } \text { et al., } \\
\text { 2017) } \\
\text { (Bhattacharya } \\
\text { and Alpas, }\end{array}$ \\
& Hood & Aluminium & Honda. & 2017) \\
& Panel & & & (Ismail and \\
Mohamed,
\end{tabular}


Figure 3 - Flow chart of the methodology adopted in this research

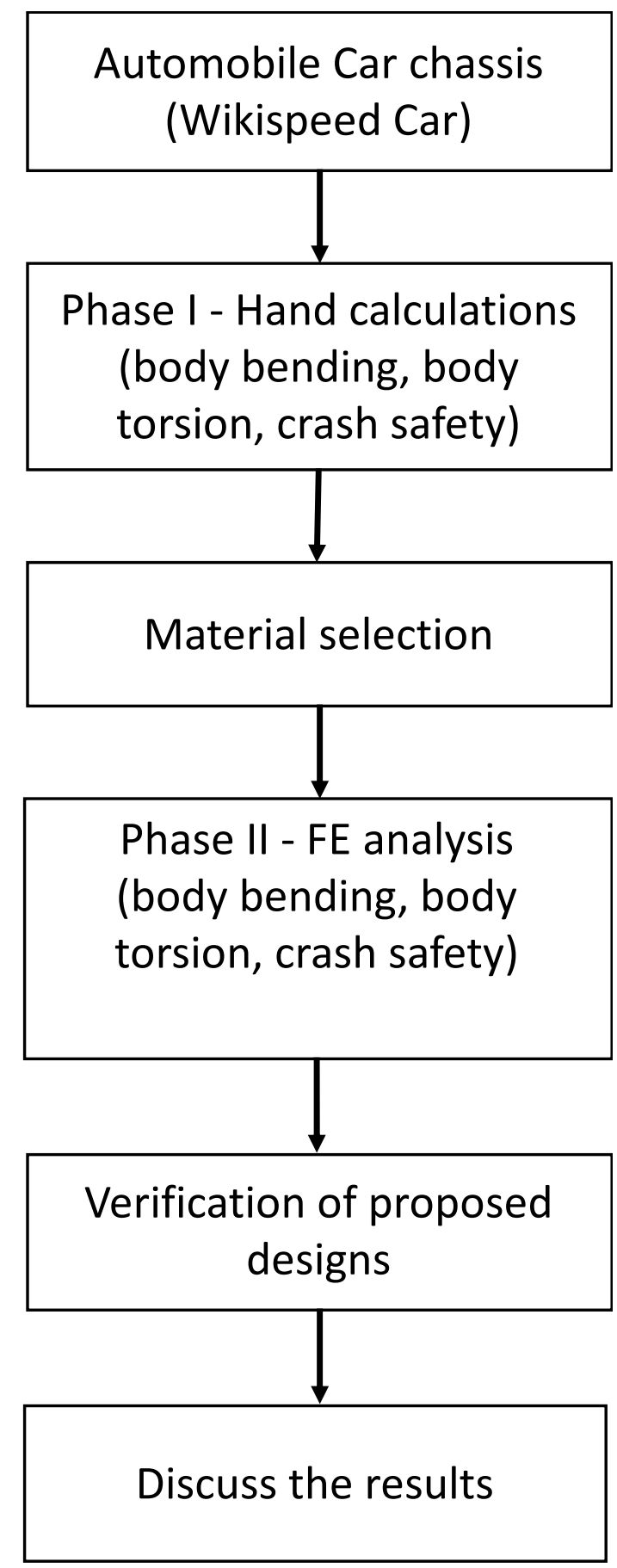


Figure 4 - The Wikispeed Body Structure, and Chassis Suspension Module (Wikispeed.org, 2017)

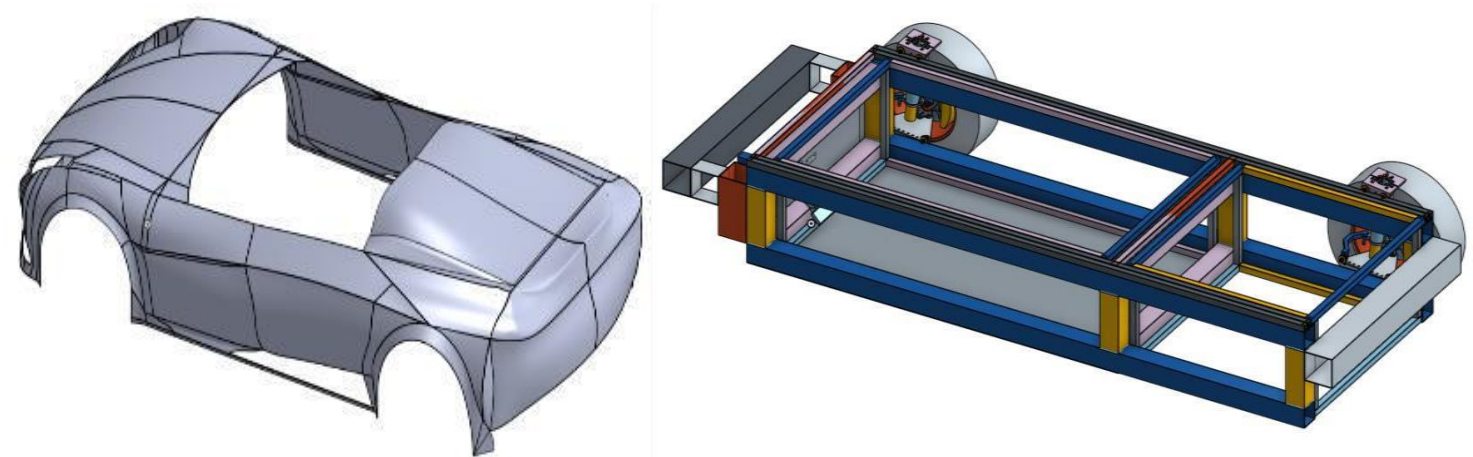


Table 2 - Alternative Material Relative Mass and Cost Substituting Aluminium

\begin{tabular}{ccc}
\hline Material & Relative cost & Relative cost \\
\hline Magnesium EN-MB10020 & $64.1 \%$ & $104 \%$ \\
Structural Steel BS EN & $289 \%$ & $24.5 \%$ \\
100253:2004 & & \\
\hline
\end{tabular}


Figure 5 - FE Analysis on One of the Rocker Beams made from Steel

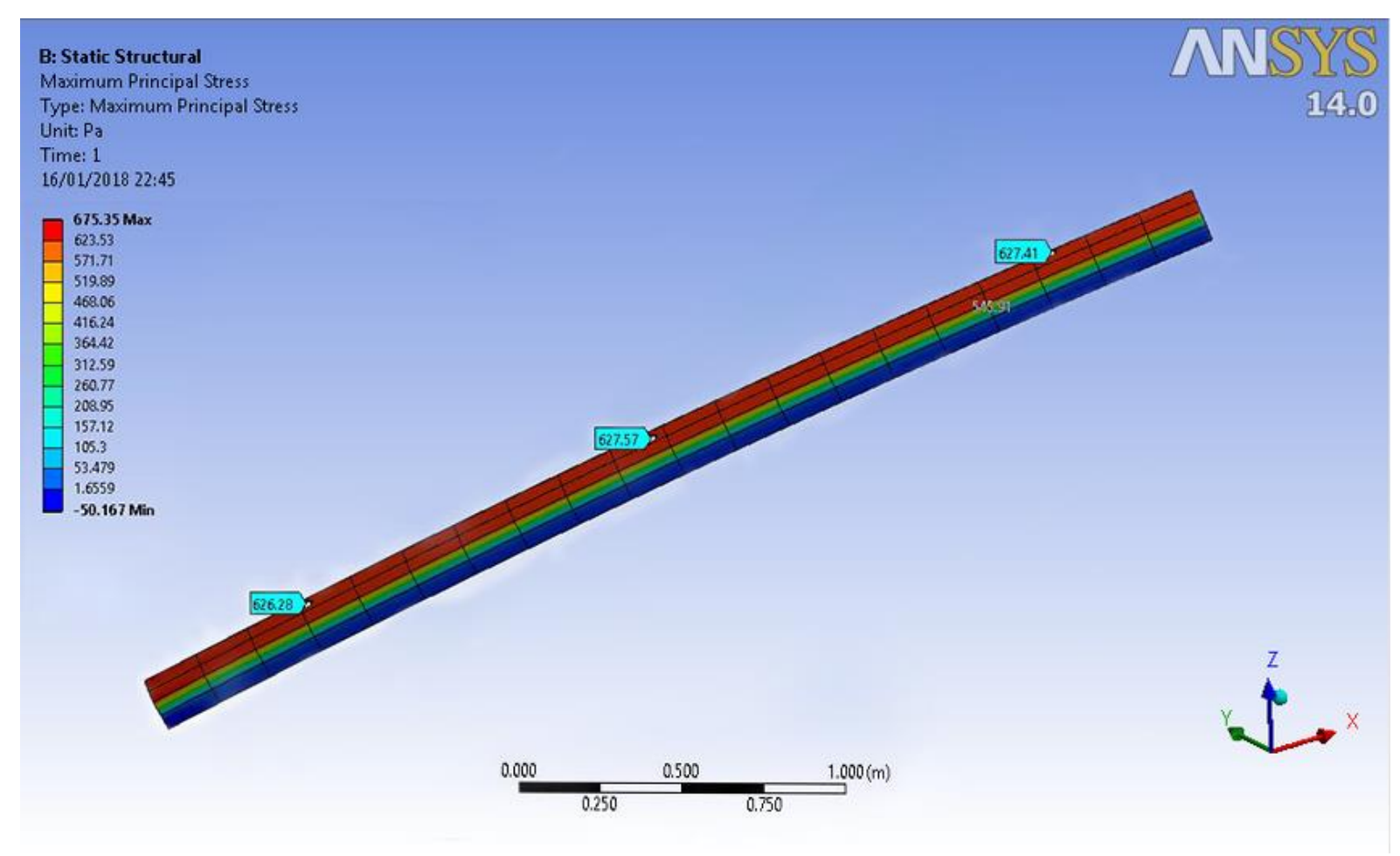


Table 3 - Results of Rocker Bending Analysis

\begin{tabular}{lrrr}
\hline Material & \multicolumn{1}{l}{ Steel } & Aluminium & Magnesium \\
& & & \\
\hline Megapascal (MPa) & 626.40 & 218.90 & 136.90 \\
KiloNewtons per Metre (kNn/m) & 23.66 & 8.27 & 5.17 \\
Weight (kg) & 31.60 & 10.92 & 7.00 \\
Price (£ UK Sterling) & 13.08 & 19.66 & 19.55 \\
\hline
\end{tabular}


Figure 6 - Bending Moment and Shear Force Diagram using 100\% Structural Steel on the Car Chassis

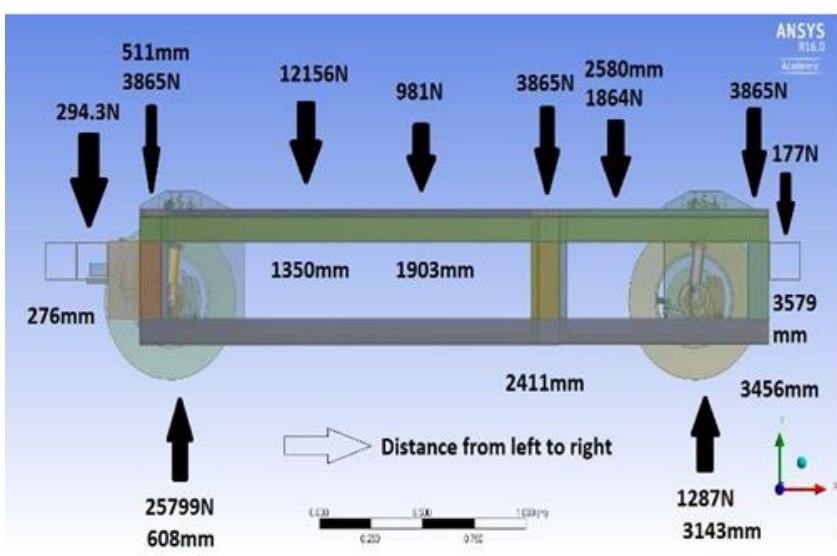

Shear Force Diagram for $1 \mathrm{~g}$ Static

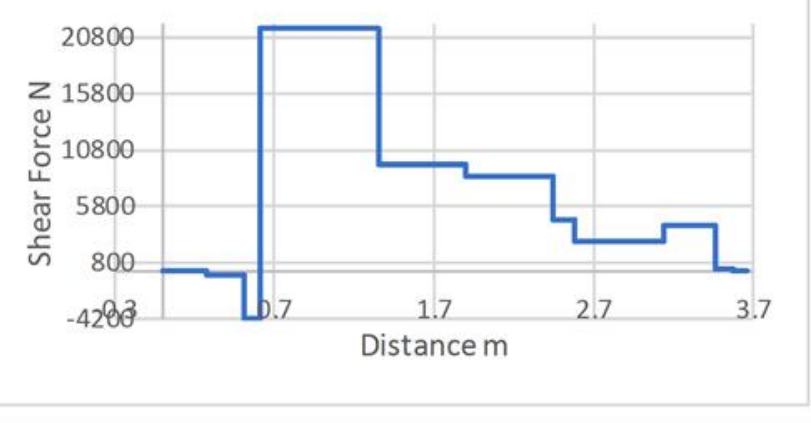


Table 4 - Chassis Stiffness

\begin{tabular}{llll}
\hline Constants & Steel & Aluminium & Magnesium \\
\hline Mass & $500 \mathrm{~kg}$ & $425 \mathrm{~kg}$ & $375 \mathrm{~kg}$ \\
$\mathrm{l}$ & 2,540 & 2,540 & 2,540 \\
$\mathrm{~L}(\mathrm{~mm})$ & 4,070 & 4,070 & 4,070 \\
$\mathrm{Fn}(\mathrm{Hz})$ & 25 & 25 & 25 \\
$\mathrm{k}\left(\mathrm{kg} / \mathrm{s}^{2}\right)$ & $4,855,368.68$ & $4,127,063.38$ & $3,641,526.5$ \\
$\mathrm{~N} / \mathrm{mm}$ & $4,855.36$ & $4,127.06$ & $3,641.52$ \\
\hline
\end{tabular}


Table 5 - Torsional Calculation Results

\begin{tabular}{cccc}
\hline Material & Steel & Aluminium & Magnesium \\
\hline$\theta_{\text {Rocker }}$ & $2.99 \mathrm{deg}$ & $8.91 \mathrm{deg}$ & $14.48 \mathrm{deg}$ \\
& & & \\
e & & $1.11 \mathrm{e}-5 \mathrm{M}^{2}$ & $1.11 \mathrm{e}-5 \mathrm{M}^{2}$ \\
e $_{\text {Hinge pillar }}$ & $3.77 \mathrm{e}-6 \mathrm{M}^{2}$ & $1.71 \mathrm{e}-6 \mathrm{M}^{2}$ & $1.71 \mathrm{e}-6 \mathrm{M}^{2}$ \\
$\mathrm{~F}$ & $3.77 \mathrm{e}-6 \mathrm{M}^{2}$ & $68.93 \%$ & $77.42 \%$ \\
$\sigma$ & $41.8 \%$ & $70.43 \mathrm{MPa}$ & \\
$\mathrm{K}$ & & $12879.8 \mathrm{Nm} / \mathrm{deg}$ & \\
\hline
\end{tabular}


Figure 7 - Total Deformation Plot on the Top Frame

$$
\begin{aligned}
& \text { A: Static Structural } \\
& \text { Total Deformation } \\
& \text { Type: Total Deformation } \\
& \text { Unit: } m \\
& \text { Time: } 1 \\
& \text { 27/02/2018 21:52 }
\end{aligned}
$$

\begin{tabular}{|l}
0.0474 Max \\
0.0422 \\
0.0369 \\
0.0316 \\
0.0263 \\
0.0211 \\
0.0158 \\
0.0100 \\
0.0052 \\
0 Min
\end{tabular}
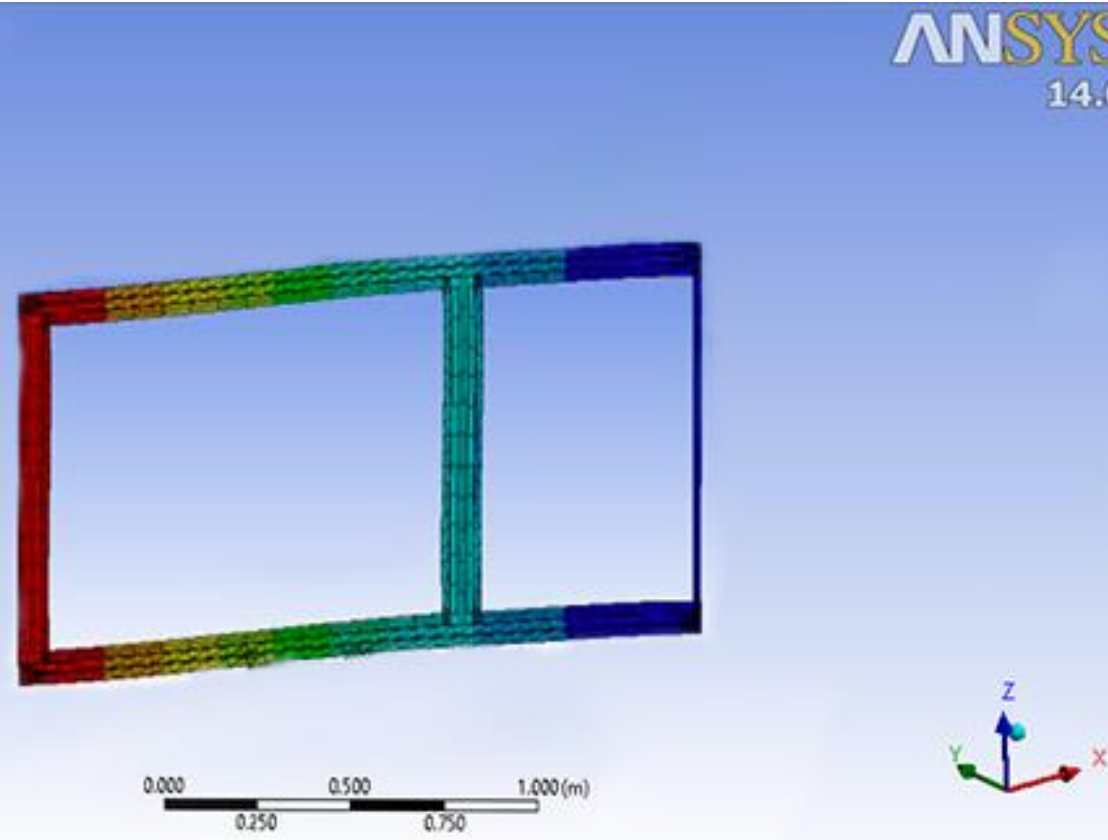
Table 6 - Load at which One Rocker Yields

\begin{tabular}{ccrc}
\hline Material & Steel & Aluminium & Magnesium \\
\hline PuLt & \multicolumn{2}{c}{ Equation 3.1} & \\
& $390.57 \mathrm{kN}$ & $250.34 \mathrm{kN}$ & $102.84 \mathrm{kN}$ \\
PuLt & $268.88 \mathrm{kN}$ & Equation 3.2 & $78.30 \mathrm{kN}$ \\
Average & $329.73 \mathrm{kN}$ & $221.31 \mathrm{kN}$ & $90.47 \mathrm{kN}$ \\
\hline
\end{tabular}


Table 7 - Average Crush Force of One Rocker

\begin{tabular}{clll}
\hline Material & Steel & Aluminium & Magnesium \\
\hline & & & \\
$\sigma_{\mathrm{y}}$ & $205 \mathrm{MPa}$ & $241 \mathrm{MPa}$ & $65 \mathrm{MPa}$ \\
Avg crush F & $118.2 \mathrm{kN}$ & $129.64 \mathrm{kN}$ & $61.43 \mathrm{kN}$ \\
\hline
\end{tabular}


Table 8: Crush Efficiency of the Wikispeed Car

\begin{tabular}{ll}
\hline Parameter & Value \\
\hline $\mathrm{V}$ & $17.78 \mathrm{~m} / \mathrm{s}(64 \mathrm{~km} / \mathrm{h})$ \\
$\mathrm{a}_{\max }$ & $28 \mathrm{~m} / \mathrm{s}^{2}$ \\
$\mathrm{M}$ & $702 \mathrm{~kg}$ \\
$\mathrm{~F}_{\max }$ & $192.83 \mathrm{kN}$ \\
Crush efficiency & $126.72 \%$ \\
\hline
\end{tabular}


Appendix 1 - Bending Formulae

$$
\begin{aligned}
& I=\text { second moment of area } \\
& \sigma_{C R}=\text { critical stress } \\
& k=\text { plate buckling coefficient } \\
& E=\text { Young's modulus } \\
& \mu=\text { Poisson's ratio } \\
& M_{C R}=\text { critical moment } \\
& \omega_{n}=\text { natural frequency } \\
& k=\text { body bending stiffness } \\
& f_{n}=\text { primary bending frequency } \\
& \sigma_{C R}=\frac{k \pi^{2} E}{12\left(1-\mu^{2}\right)\left(\frac{b}{t}\right)^{2}} \\
& I=\frac{B H^{3}}{12} \\
& y=\frac{h}{2} \\
& \sigma_{C R}=\frac{\mathrm{M}_{C R} y}{I} \\
& \omega_{n}=\frac{22.4}{\sqrt{48}}\left(\frac{l}{L}\right)^{3} \sqrt{\frac{k}{M}} \\
& k=0.09566\left(\frac{l}{L}\right)^{3} M\left(2 \pi f_{n}\right)^{2}
\end{aligned}
$$


Appendix 2 - Torsion Formulae

$J_{\text {eff }}=$ torsion constant of the side raii

$A=$ cross-sectional area

$t=$ thickness

$S=$ perimeter

$T=$ Torque

$\emptyset=$ angle of twist

$\tau=$ shear stress

$(G t)_{e f f}=$ effective shear rigidity of a shear-resistant member

$K_{s}=$ Frame shear stiffness in plan view

$K_{j}=$ Joint stiffness

$K_{n}=$ Plan stiffness

$K=$ torsional stiffness

$J_{\text {eff }}=\frac{4 A^{2} t}{S}$

$\emptyset=\frac{T L}{G J_{e f f}}$

$\tau=\frac{T}{2 A t}$

$(G t)_{e f f}=\frac{F b}{\delta} \bar{a}$

$K_{s}=\frac{4 k_{j}}{I^{2}}$

$K_{n}=\frac{(G t)_{e f f}}{\text { Surface area }}$

$K=4 h^{2} w^{2}\left\{\frac{1}{\left(\frac{1}{K_{\text {Front }}}\right)+\left(\frac{1}{K_{\text {Rear }}}\right)+\left(\frac{1}{K_{L . \text { Side }}}\right)+\left(\frac{1}{K_{\text {R.Side }}}\right)+\left(\frac{1}{K_{\text {Bottom }}}\right)+\left(\frac{1}{K_{\text {Top }}}\right)}\right\}$

$e_{\text {beam }}=\frac{L}{6 E I}\left(3 M^{2}\right)$

$e_{\text {joint }}=\frac{M^{2}}{2 k_{j}}$ 
Appendix 3 - Crashworthiness Formulae

$w=$ effective width of plate under the stress $\sigma_{s}$

$\sigma_{C R}=$ Buckling stress for plate

$\sigma_{s}=$ maximum stress on plate

$b=$ actual width of plate

$t=$ thickness of plate

$P_{U}=$ effective section of yield

$\eta=$ crush efficiency

$V_{0}=$ initial velocity

$\Delta=$ space available for crush

$m=$ test mass

$a_{\text {max }}=$ maximum deacceleration

$F_{\text {max }}=$ maximum force

$\sigma_{y}=$ yield strength

$b=$ width of the beam

Equation 3.1: $\quad w=0.894 b \sqrt{\frac{\sigma_{C R}}{\sigma_{s}}}$

Equation 3.2: $\quad w=b \sqrt{\frac{\sigma_{C R}}{\sigma_{s}}}\left(1-0.22 \sqrt{\frac{\sigma_{C R}}{\sigma_{s}}}\right)$

$P_{U}=\sigma_{s}(4 w t)$

$\eta=\frac{V_{0}^{2}}{2 \Delta a_{\max }}$

$F_{\text {max }}=m a_{\text {max }}$

$F_{\text {avg. }}=386 t^{1.86} b^{0.14} \sigma_{y}^{0.57}$ 